\title{
The Effect of Montessori Programme on the Motion and Visual Perception Skills of Trainable Mentally Retarded Individuals
}

\author{
Mustafa Kaya ${ }^{1}$, Kadir Yildiz ${ }^{2}$ \\ ${ }^{1}$ Faculty of Sport Sciences, Erciyes University, Kayseri, Turkey, https://orcid.org/0000-0002-2438-2678 \\ ${ }^{2}$ Faculty of Sport Sciences, Manisa Celal Bayar University, Manisa, Turkey, https://orcid.org/0000-0003-3347-0319 \\ Correspondence: Mustafa Kaya, Faculty of Sport Sciences, Erciyes University, 38039, Kayseri, Turkey.
}

Received: December 12, 2018

Accepted: December 28, 2018 Online Published: January 8, 2019

doi:10.11114/jets.v7i2.3875

URL: https://doi.org/10.11114/jets.v7i2.3875

\begin{abstract}
In this research, it is aimed to examine the effects of Montessori education on the mentally retarded individuals in the special education who have had Montessori education and who have not had it.

24 trainable mentally disabled male students who had and did not have Montessori education in a private school in Kayseri participated in the study. The students were between the ages of 20-22. 12 voluntary participants constituted the experimental group who had Montessori education. The control group included 12 voluntary mentally disabled individuals. While the control group had a routine training for 8 weeks, the experimental group had Montessori education program for 8 weeks. In addition, mothers of the students in the experimental group were included in the training program. The mentally disabled individuals had movement and visual perception skills tests.

When the results of the movement perception skills in the experimental and control groups were reviewed, no significant differences were found in the movement skill variables according to the values $(p>0.05)$. While the pretest posttest values in the mentally retarded individuals in the experimental group revealed significant difference $(\mathrm{p}<0,05)$, no difference occurred only in the left foot balance test $(\mathrm{p}>0,05)$. All pretest posttest values depending on the movement revealed significant difference in the control group $(\mathrm{p}<0,05)$.

As a result, when the effect of the Montessori program on the movement skills of trainable mentally retarded people was examined, no significant difference was found between the values of the control group, and Montessori education gave similar values as the classical education. Thus, it was concluded that it was advisable Montessori education program to be used widely. When its effect on the visual perception skills was examined, it could be stated that the posttest averages of the each visual perception sub-scale average revealed an increase except the shape-ground connection. Consequently, when the movement skills of the trainable mentally retarded individuals were reviewed, no difference was found in the control group values, and Montessori education values were similar to classical education. Therefore, it is concluded that Montessori education program should be used widely.
\end{abstract}

Keywords: montessori, trainable mentally retarded, movement, visual perception

\section{Introduction}

Sports and movement activities which have important functions such as healthy life and adaptation to society have an important function in disabled individuals' adapting the society because people with disabilities also need to act as people who normally develop (Açak \& Kaya, 2015). A movement skill in children with disabilities is important for their quality of life (Aksay et al., 2011). These show that mentally disabled individuals need both physical and interpersonal requirements. Such deficiencies can cause anger. The concept of anger, which is expressed as aggression shortly, can cause unexpected conditions in disabled individuals such as weakness in family and social relationships, weak physical state and lack of education (Ryan, Ashwood, \& Puckeridge, 2010). It is certain that parents will be more willing to develop the knowledge and skills that they think are necessary for their children and that they will be less willing to teach the knowledge and skills that they consider insignificant. These considerations affect the structure of the education and determine the direction and the quality of the activities (Barbarin et al., 2008). Rather than training the families, it is necessary to provide the participation of the families and maintain the education in the cooperation of families and the school. Family participation activities are divided as institution centered and home centered. Today it is 
seen that educational institutions implement education programs supported with family involvement that provide the involvement of the parents in different degrees (Kagitcibasi, Sunar \& Bekman, 2001). One of these programs is Montessori program with family involvement through various activities (Boehnlein, 1990). Montessori Education Method, which was developed by Montessori, is used in children education successfully in many countries in the world (Ansari \& Winsler, 2014). In the evaluations after the Montessori pre-school programs, which supported by parents, it is found that parents are highly satisfied generally (Kahn, 1990). The researches on parent programs have revealed that active involvement of the parents in their children's education provides two significant advantages. There is a positive relation between the parent involvement in the school activities and student success (Epstein, 1986). Montessori believes that children learn best in a prepared environment that they can do something for themselves. The first purpose of the prepared environment in Montessori is to make the developing child independent from adults as much as possible (Montessori, 2015). Montessori education program is an education program that follows the children's eagerness to learn and that is related to this process. Also, the program shows individuals how they learn in the easiest and best way by self-education (Oğuz \& Köksal Akyol, 2006). Montessori method has helped to change the lives of small children. It has helped learning to be more efficient with the principles it has brought to education. One of the main principles of Montessori education is action and perception. Action and perception is called as the vital point that creates a link of Montessori sense and action activity with relationship systems and environment. In the method, activities that allow children to move are important. Action is the center of the children. Actions or physical activities are important factors in mental development. Montessori states that thinking is expressed without words, but by hands (Yıldı, 2018). Visual perception is defined as gaining knowledge through visual stimuli and interpreting it after processed (Akçin, 1993). Therefore, individuals learn reading, writing and skills that they need for school success by means of visual perception skills (Sağol,1998). Akdemir (2006) defines the concept of visual perception as the skill of recognizing and identifying visual stimuli and interpreting them by associating them with previous experiences. Individuals having visual perception problems fall behind in learning. Children having weak skills of percepting their immediate environment cannot see the relationship of objects and written expressions with themselves. There is absence of skill in their movements. They have difficulty to understand the words indicating place and location (Sağol, 1998). Therefore, it is expected their movement skills to increase as a result of good visual perception and increasing place and location relationships.

In this research, it is aimed to examine the effect of the Montessori education program given to the mentally retarded individuals in the special education and their mothers on the movement and visual perception skills.

\section{Method}

\subsection{Research Model}

The research has designed in the experimental scanning method, one of the quantitative research methods. Pretest and posttest measurements were obtained in the research. Two groups formed as experimental group and control group, and pretest and posttest measurements were applied in both groups. At the end of the 8-week period, posttest was applied in to the experimental group in order to test the effect of the education.

\subsection{Research Group}

The study group of the study consists of trainable mentally handicapped students between the ages of 20-22 who receive and do not receive Montessori training in a private school in Kayseri in the 2017-2018 academic year and their mothers. Experimental and control groups were determined by random cluster sampling method. A total of 24 volunteers were included in the study, 12 in the experimental group and 12 in the control group.

\subsection{Data Collection Tools}

Montessori training program was applied and movement and perception tests were performed in the research. In the planning of the study, open-ended questions were asked to school educators and parents and needs analysis was conducted. Content analysis was performed on these questions and the initial needs were determined. The answers were effective in deciding on family education, the willingness of the mother to participate and our understanding of the time of day when they could participate in the training. The second need analysis was conducted on the group of mothers willing to participate in the training. These interviews were effective in determining the program. After the information from the mothers, it was decided to apply motion tests and visual perception tests to the individuals in the study group in order to measure the development of mentally handicapped individuals at the age of 20-22.

\section{Montessori Training Program Application}

First, volunteers between the ages of 20-22 who were trained with Montessori education method were determined. The mothers were invited to the school. The training started with the voluntary mothers. Total 12 mothers volunteered to participate in the program. In the study group, voluntary individuals between the ages of 20-22 and their mothers were 
taken into consideration. One of the groups was experimental group, and the other was control group. In the research, the effect of the Montessori Parent Support Training given to the mothers on their children was evaluated. In the experimental group, "Montessori Parent Support Training Program" was given to the mothers 1 day a week for 3 hours, totally for 8 weeks and 24 hours. The 8 -week training program is as follows:

1 st week - The life and philosophy of Montessori,

2nd week - Montessori principles,

3rd week - Arrangement of the environment according to Montessori principles,

4th week - Communication in Montessori education and basic communication training,

5th week- Montessori materials and their characteristics,

6th week - Daily life materials applications,

7th week - Home applications and discussing these application in the classroom, discussing applications, dramas, etc., giving homework,

8th week - Sensory materials, their applications and evaluations.

Personal information form: Personal information form prepared by the researches included the variables such as the ages, education status and working status of the mothers of the participants in the experimental and control groups, and the gender of the mentally retarded children.

\section{Motion and perception tests}

Standing broad jump test: The test was performed in order to measure the explosive power of the extensor leg muscles of the subject. Açıkada (2008) states that branches performed at maximal speed such as jumping are determinant for the athletes' transforming energy to power. The participants were asked to take position as their arms are behind, knees are flexed, the body was leaning forward slightly and to jump forward with two feet. The same test was performed on each participant three times and the best score was recorded as $\mathrm{cm}$.

Medicine ball throw test (MBT): Vossen et al., (2000) made the participants sit according to the procedure accepted for MBT test. Thighs are supported horizontally, knees are bent in a $90^{\circ}$ angle supported straight against the back support and ankles are on the ground fastened to the floor. The participants fastened to the armchair via elastic bands placed around their body at the chest level from the armchair. This position were standardized to provide more stability and to minimize the movements of the body during the performance. For the throw, a 3-kilo of medicine ball was located at the height of the sternum. The throw was performed with two hands, and if the participant did not follow the determined standards, the throw was ignored. The distance from the throw point to the point that the ball first contacted was measured. Each participant performed three throws with 5-minute intervals, and the best result was recorded.

Flexibility measurement: In the flexibility measurement, the flexibility measurement procedure which was performed by Tamer (2000) was used. The volunteers sat on the floor, crossed their legs and they were asked to set their soles against the table without shoes. They reached out forward on the table as much as possible without bending their knees. The most extreme point in which their fingers stretched was measured in $\mathrm{cm}$. They repeated it three times and the best score they reached was recorded.

Handgrip strength measurement: In the measurements of hand dynamometer measurement method performed according to the Zorba's (2000) procedure, Baseline digital hand dynamometer that could measure the strength up to $100 \mathrm{~kg}$ was used. Dynamometers fitting to the hand sizes of the subjects were used for the handgrip strength measurement. The arms were straight and there was a 10-15 degree of angle from the shoulders. The maximum strength measurement was performed with the active hand in two repetitions. The best values were recorded in $\mathrm{kg}$.

$20 \mathrm{~m}$ sprint test: $20 \mathrm{~m}$ speed measurement was performed by newtest photocell according to the procedure stated in the study of Hetzler, Stickley, Lundquist, \& Kimura (2008). The photocells were 1 meter high from the floor. The subjects performed the test indoor and repeated the run twice. The best score was recorded in sec. While 20 meter sprint test measures the acceleration in track athletes, it is also used to measure the maximum speed in some team athletes.

Standing Stork Test - Blind: According to the balance measurement in the study by Mackenzie (2005), the participants were asked to stand comfortably on both feet with their hands on their hips. Then, they were asked to lift one leg and place the toes of the lifted leg against the side of the other kneecap. Next, the participants were asked to raise the heel of the fixed foot to stand on their toes. During this process, the participants were asked to hold this position for as long as possible without letting the heel touch the floor and other foot move away from the kneecap. The time of keeping balance was recorded in sec. The test was performed for both feet with open eyes.

Evaluating Visual Perception Skills: In order to evaluate visual perception skills of the mentally retarded individuals, 
shape-ground connection, visual coupling, visual identification and the inter-objects space relationships, visual perception skill criterion developed by (Akdemir, 2006). Wooden geometric figure identification tool in four different colors and in four different geometric figures was used as pretest and posttest in order to evaluate visual perception. In order to evaluate the activity according to visual perception skills of the mentally retarded individuals, shape-ground connection, visual coupling, visual identification and the inter-objects space relationships, correlational survey model was used.

In the first stage of the test, the participants were asked to find the basic figures and to place them on the wooden setting. In the second stage, they were asked to bring the figures of the same color together. In the third stage it was asked to put the figures of the same color in the boxes of the same color. In the fourth and last stage, it was asked to place the figures in their spaces of the same color to evaluate the inter-objects space and figure relationship. The state of volunteers' doing or not doing the given instructions was marked as $1-0$ on the evaluation form and graded (Akdemir, 2006).

\subsection{Statistical Analysis of Data}

The distribution normality in the analysis of the obtained data was tested by Shapiro-Wilk test. Median and (25-75\%) percentage values were given as statistical indication. Mann-Whitney $\mathrm{U}$ was used in comparing independent groups, and Wilcoxon signed ranked test was used for comparing dependent groups. Significance level was taken as $\mathrm{p}<0.05$.

\section{Findings}

In this part of the research, statistical analysis and interpretation of the data obtained are given.

Table 1. Test results of the experimental $(n=12)$ and control $(n=12)$ groups in terms of some demographic variables

\begin{tabular}{|c|c|c|c|c|c|}
\hline Variable & Group & Median & $(25 \%-75 \%)$ & $\mathbf{Z}$ & $\mathbf{p}$ \\
\hline \multirow{2}{*}{ Mother's age (year) } & Experimental & 55.0 & 51.3- 56.8 & \multirow{2}{*}{-0.117} & \multirow{2}{*}{0.907} \\
\hline & Control & 55.5 & $50.5-56.8$ & & \\
\hline \multirow{2}{*}{ Mother's educational background } & Experimental & 2.5 & $1.3-3.0$ & \multirow{2}{*}{-0.185} & \multirow{2}{*}{0.853} \\
\hline & Control & 2.5 & $1.3-3.0$ & & \\
\hline \multirow{2}{*}{ Mother's employment status } & Experimental & 2.0 & $1.3-2.0$ & \multirow{2}{*}{-0.848} & \multirow{2}{*}{0.397} \\
\hline & Control & 2.0 & $1.0-2.0$ & & \\
\hline \multirow{2}{*}{ Volunteers' age (year) } & Experimental & 21.0 & $20.0-22.0$ & \multirow{2}{*}{-0.245} & \multirow{2}{*}{0.806} \\
\hline & Control & 21.0 & $20.0-22.0$ & & \\
\hline \multirow{2}{*}{ Volunteers' stature (cm) } & Experimental & 160.0 & $158.0-165.0$ & \multirow{2}{*}{-2.115} & \multirow{2}{*}{$0.034 *$} \\
\hline & Control & 166.0 & $161.8-169.8$ & & \\
\hline \multirow{2}{*}{ Volunteers' body weight (kg) } & Experimental & 67.5 & $59.3-80.5$ & \multirow{2}{*}{-0.753} & \multirow{2}{*}{0.451} \\
\hline & Control & 72.0 & $68.5-77.3$ & & \\
\hline
\end{tabular}

A significant difference was found only between the stature values of the participants $(p<0.05)$. No significant differences were found between the values of mothers' ages, educational backgrounds, employment status, volunteers' ages and body weights ( $\mathrm{p}>0.05)$.

Table 2. The comparison of the pretest motion perception skills of the experimental $(n=12)$ and control $(n=12)$ groups.

\begin{tabular}{|c|c|c|c|c|c|}
\hline Variable & Group & Median & $(25 \%-75 \%)$ & $\mathbf{z}$ & p \\
\hline \multirow{2}{*}{ Right foot balance (sec) } & Experimental & 2.5 & $1.8-2.9$ & \multirow{2}{*}{-0.173} & \multirow{2}{*}{0.862} \\
\hline & Control & 2.5 & $1.8-3.2$ & & \\
\hline \multirow{2}{*}{ Left foot balance (sec) } & Experimental & 2.8 & $1.9-3.1$ & \multirow{2}{*}{-0.433} & \multirow{2}{*}{0.665} \\
\hline & Control & 2.4 & $1.8-3.0$ & & \\
\hline \multirow{2}{*}{20 meter (sec) } & Experimental & 3.7 & 3.6- 3.9 & \multirow{2}{*}{-0.318} & \multirow{2}{*}{0.750} \\
\hline & Control & 3.8 & $3.5-3.9$ & & \\
\hline \multirow{2}{*}{ Standing long jump (cm) } & Experimental & 58.0 & $49.0-76.8$ & \multirow{2}{*}{-0.724} & \multirow{2}{*}{0.469} \\
\hline & Control & 61.0 & $54.0-88.0$ & & \\
\hline \multirow{2}{*}{ Medicine ball throw (cm) } & Experimental & 173.0 & $161.0-217.5$ & \multirow{2}{*}{-.347} & \multirow{2}{*}{0.729} \\
\hline & Control & 169.0 & $158.5-209.0$ & & \\
\hline \multirow{2}{*}{ Flexibility (cm) } & Experimental & 33.0 & $32.0-34.8$ & \multirow{2}{*}{-1.577} & \multirow{2}{*}{0.115} \\
\hline & Control & 31.0 & $30.0-33.8$ & & \\
\hline \multirow{2}{*}{ Hand grip (kg) } & Experimental & 24.5 & $22.3-26.8$ & \multirow{2}{*}{-0.698} & \multirow{2}{*}{.485} \\
\hline & Control & 25.5 & $23.3-26.8$ & & \\
\hline
\end{tabular}

When the pretest results of the motion perception skills in Table 2 are examined, no significant difference was found in all movement skill variables of the experimental and control groups $(\mathrm{p}>0.05)$. 
Table 3. The comparison of the posttest motion perception skills of the experimental $(n=12)$ and control $(n=12)$

\begin{tabular}{llcccc}
\hline Variable & Group & Median & $\mathbf{( 2 5 \% - 7 5 \% )}$ & $\mathbf{z}$ & $\mathbf{p}$ \\
\hline \multirow{2}{*}{ Right foot (sec) } & Experimental & 2.8 & $2.1-3.1$ & \multirow{2}{*}{0.058} & 0.954 \\
& Control & 2.7 & $2.3-3.2$ & & \\
Left foot (sec) & Experimental & 3.0 & $2.0-3.2$ & -0.578 & 0.563 \\
& Control & 2.9 & $2.7-3.5$ & & \\
\multirow{2}{*}{$\mathbf{2 0}$ meter (sec) } & Experimental & 3.5 & $3.3-3.8$ & -0.173 & 0.862 \\
\multirow{2}{*}{ Standing long jump (cm) } & Control & 3.5 & $3.2-3.8$ & & \\
& Experimental & 62.0 & $55.5-84.3$ & -0.896 & 0.370 \\
Medicine ball throw (cm) & Control & 68.5 & $62.3-87.0$ & & \\
& Experimental & 176.5 & $164.5-224.3$ & -0.087 & 0.931 \\
Flexibility (cm) & Control & 184.5 & $172.3-222.8$ & & \\
& Experimental & 24.0 & $22.3-25.0$ & -1.271 & 0.204 \\
Hand grip (kg) & Control & 24.5 & $24.0-27.8$ & & \\
& Experimental & 27.5 & $25.0-28.0$ & -0.468 & 0.640 \\
\hline
\end{tabular}

When the posttest results of the motion perception skills in Table 3 were examined, no significant differences were found in all motion skill variables of the experimental and control groups ( $\mathrm{p}>0.05)$.

Table 4. The test results of the pretest and posttest comparisons of the experimental group $(n=12)$

\begin{tabular}{|c|c|c|c|c|c|c|}
\hline \multirow[b]{3}{*}{ Variable } & \multicolumn{5}{|c|}{ Experimental Group } & \multirow[b]{3}{*}{$\mathbf{p}$} \\
\hline & \multirow{2}{*}{$\frac{\text { Pre-test }}{\text { Median }}$} & & \multicolumn{3}{|c|}{ Post-test } & \\
\hline & & $(25 \%-75 \%)$ & Median & $(\% 25-\% 75)$ & $\mathbf{Z}$ & \\
\hline Right foot balance (sec) & 2.52 & $1.81-2.87$ & 2.82 & $2.05-3.13$ & $-2,048$ & $0.041 *$ \\
\hline Left foot balance (sec) & 2.83 & $1.91-3.13$ & 2.97 & $2.04-3.18$ & $-1,601$ & 0.109 \\
\hline 20 meter (sec) & 3.73 & $3.59-3.88$ & 3.49 & $3.29-3.78$ & $-3,071$ & $0.002 * *$ \\
\hline Standing long jump (cm) & 58.00 & $49.00-76.75$ & 62.00 & $55.50-84.25$ & $-3,088$ & $0.002 * *$ \\
\hline Medicine ball throw $(\mathrm{cm})$ & 173.00 & $161.00-217.50$ & 176.50 & $164.50-224.25$ & $-3,068$ & $0.002 * *$ \\
\hline Flexibility $(\mathrm{cm})$ & 33.00 & $32.00-34.75$ & 24.00 & $22.25-25.00$ & $-3,106$ & $0.002 * *$ \\
\hline Hand grip (kg) & 24.50 & $22.25-26.75$ & 27.50 & $25.00-28.00$ & $-2,376$ & $0.017 *$ \\
\hline
\end{tabular}

$* \mathrm{p}<0.05 \quad * * \mathrm{p}<0.01$

When Table 4 was examined, a significant difference was found between the pretest and posttest values of the right foot balance, 20-meter sprint, standing long jump, medicine ball throw, flexibility and handgrip tests $(\mathrm{p}<0.05)$. No significant difference was found in left foot balance value $(\mathrm{p}>0.05)$.

Table 5. The test results of the pre-test and post-test comparisons of the control group $(\mathrm{n}=12)$

\begin{tabular}{|c|c|c|c|c|c|c|}
\hline \multirow[b]{3}{*}{ Variable } & \multirow[b]{3}{*}{ Median } & \multicolumn{5}{|c|}{ Control Group } \\
\hline & & \multicolumn{2}{|l|}{ Pre-test } & & & Post-test \\
\hline & & $(25 \%-75 \%)$ & Median & $(25 \%-75 \%)$ & $\mathbf{z}$ & $\mathbf{p}$ \\
\hline Right foot balance (sec) & 2.48 & $1.81-3.21$ & 2.72 & $2.31-3.23$ & $-2,275$ & $0.023^{*}$ \\
\hline Left foot balance (sec) & 2.43 & $1.85-3.00$ & 2.89 & $2.71-3.46$ & $-2,746$ & $0.006 * *$ \\
\hline 20 meter (sec) & 3.77 & $3.52-3.89$ & 3.53 & $3.22-3.85$ & $-2,353$ & $0.019 *$ \\
\hline Standing long jump (cm) & 61.00 & $54.00-88.00$ & 68.50 & $62.25-87.00$ & $-2,751$ & $0.006 * *$ \\
\hline Medicine ball throw $(\mathrm{cm})$ & 169.00 & $158.50-209.00$ & 184.50 & $172.25-222.75$ & $-2,237$ & $0.025^{*}$ \\
\hline Flexibility (cm) & 31.00 & $30.00-33.75$ & 24.50 & $24.00-27.75$ & $-3,064$ & $0.002 * *$ \\
\hline Hand grip (kg) & 25.50 & $23.25-26.75$ & 27.50 & $25.25-29.00$ & $-2,557$ & $0.011 *$ \\
\hline
\end{tabular}

When the pre-test and post-test results of the control group in Table 5 were examined, a significant difference was found in all values $(\mathrm{p}<0.05)$. 


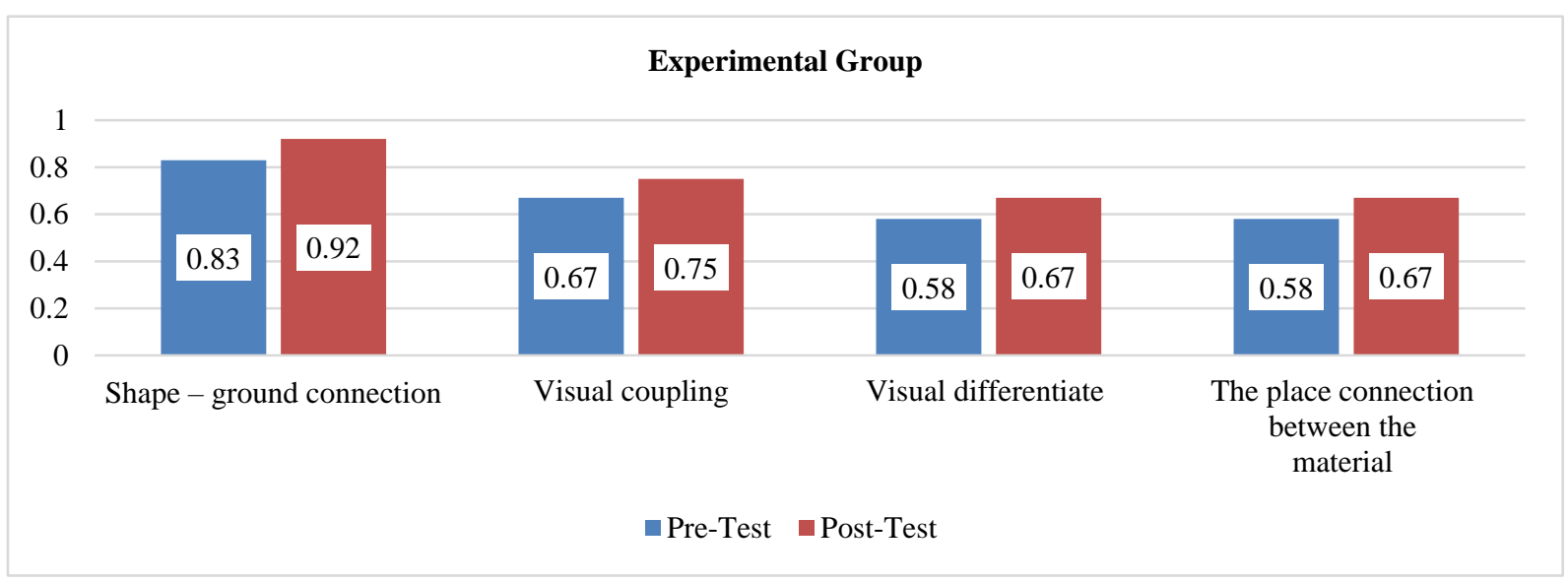

Graph 1. Experimental group visual perception test

When Graph 1 is examined, it can be stated that the averages of each visual perception sub-scale except shape-ground connection show increase in favor of the posttests.

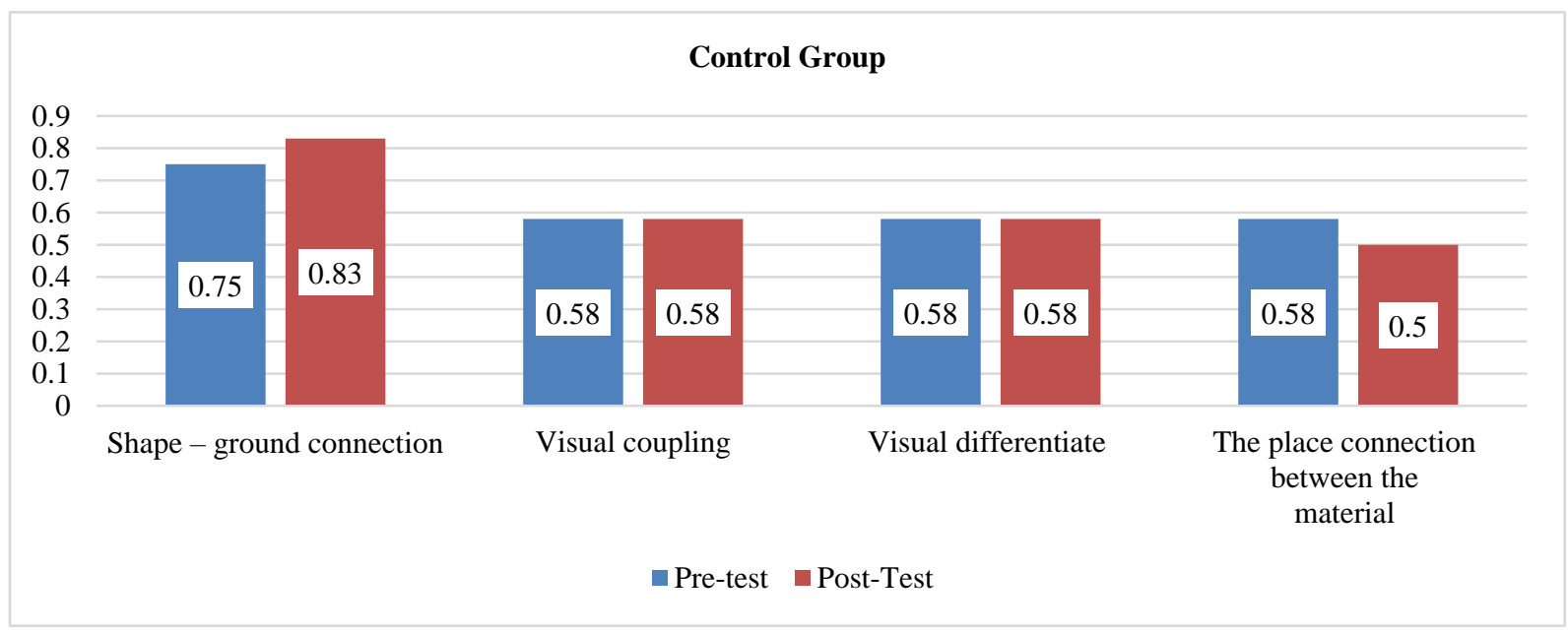

Graph 2. Control group visual perception test

When Figure 2 was examined, it can be stated that the averages of each visual perception sub-scale pretest and posttest except the shape-ground connection have not differentiated

\section{Discussion and Conclusion}

Montessori education model, which was initially designed to teach young children cognitive and social skills, involves individualized teaching designed to improve practical life skills and sensory experiences (Montessori, 2014). In this study, the effect of Montessori education method on the improvement of the movement and perception skills and visual perception skills of the trainable mentally retarded individuals and their mothers was investigated.

In the study, a significant difference was found between the pretest and posttest values of the right foot balance, left foot balance, 20 meter sprint, staying long jump, ball throw, flexibility and handgrip strengths in the experimental and control groups which were consisted of trainable mentally retarded individuals $(p<0.05)$. Only in the experimental group, no significant difference was found in the left foot balance value ( $p>0.05$ ). Akyol and Güllü (2014) state that if manual ability of the mentally retarded individuals develops, daily live activity and gross, motor function develops. Another study was conducted on basketball players for 12 weeks. In this study, pretest and posttest results of the balance performance values were compared. The performance was conducted while one foot lifted first with open eyes and then closed eyes, and the balance values were measured before and after the basketball workout. In the comparison, no significant difference was found only in the balance position while the left foot was lifted with open eyes, but significant difference was found in all other parameters (Atan et al., 2016). When the obtained values are compared with the literature data, it is seen that indifference in the left foot balance values are supported by the literature. It is considered that since the students of the school we conduct our study at has more intense sport activities, speed and strength skills improves and their values are found significant. However, the development of a sense of balance 
achieves perfection with good education. Therefore, it is necessary to perform regular balance exercises from easy to difficult in kindergartens and preschool. Tınazc1, Emiroğlu, \& Burgul, (2004) reports that they have found a significant difference between the flexibility, explosive power and right handgrip strengths in their study conducted on girls and boys between the ages of 7-11. In this study, when the ball throw, standing long jump and handgrip strength values are reviewed, it is seen that there is a significant difference between the pretest and posttest values of the experimental and control groups $(\mathrm{p}<0.05)$. These results are supported by the study conducted by Tinazc1 et al., (2004).

It is reported in the research conducted on trainable mentally retarded males by Savucu et al., (2006) that a 12-week basketball training has affected right hand grip strength in a positive way. In our study, a significant difference was found between the pretest and posttest values of the experimental and control groups $(p<0.05)$. Since these values are similar to the result found by Savucu et al., it is considered that the handgrip strength of the mentally retarded individuals at this age group is between these values. In the study conducted by Karahan et al., (2007) related to mentally retarded people, it is stated that flexibility values has increased. Atan et al., (2016) state that posttest values has increased when compared to pretest values in flexibility values in the study conducted on the motor skills of mentally retarded individuals (Atan et al., 2016). Merriman et al., (1996) conducted a study with mentally handicapped 3 days a week for 12 weeks, and they stated that flexibility ability improved significantly. In the study, when the flexibility values of the trainable mentally retarded individuals are reviewed, it is observed that there is a significant difference in the pretest and posttest values of the experimental and control groups $(\mathrm{p}<0.05)$. These results are seen to be supported by the literature.

It is reported in a meta-analysis study on the Montessori education method in Turkey that experimental researches have gained prevalence since 2005, the researches has included especially pre-school period and the efficiency of Montessori education method has been emphasized (Kayıl1, 2016). In the study conducted by Ervin et.al, it is stated that Montessori classroom environment derives children (60\%) to help others in different ways, and most of the children learn how to resolve their own conflicts without adult assistance (Ervin, Wash, \& Mecca, 2010). Lillard (2008) states that Montessori applications are efficient since they simplify the tasks for children, provide immediate feedback and encourage learning. Therefore, Montessori program can be said to have a significant effect in the learning process.

Due to the significant differences in the pre-test and post-test values of the mothers and mentally retarded individuals receiving Montessori education, Montessori education models can be suggested to be used widely in the practices. The visual perception test with four stages performed in our study has been performed rather on healthy individuals in the literature. Therefore this study has been conducted on this field to contribute the limited literature on disabled individuals. It was determined that the post-test averages of each visual perception sub-scale increased except shape-ground connection in the experimental group. In the control group, no difference was detected in the post-test average of any visual perception sub-scale average except shape-ground connection. In his study, Akdemir examined the skills of the shape-ground connection, visual coupling, visual discrimination and inter-objects spare connection of mentally retarded students, and it is stated that no significant difference was found between the students classified as depending on their ages as between the ages of 6-12, under 9 and above 10 (Akdemir, 2006). In the study conducted to evaluate the efficiency of Montessori Education Program in motor skills, visual perception and memory, eye hand coordination and gaining fine motor skills of the children of 4-5 age group, it is stated that there is a significant difference in motor skills, visual perception and memory, eye hand coordination and fine motor skills in favor of the group receiving Montessori Education Program (Asliyüksek, 2015). Bhatia, Davis, \& Shamas-Brandt (2015) conducted a study to test the effect of the Montessori daily life skill activities on the fine motor skills and hand mastery for 8 months. In the pretest and posttest evaluations, students in the Montessori group revealed a prominent higher accuracy, speed and consistency after the test of the dominant hand. In this study, it can be stated that each visual perception sub-scale average has increased except for the shape-ground connection. It is considered that this situation is as a result of the positive contribution of the repeated skills to the level of learning.

Consequently, when the effect of Montessori program on the movement and visual perception skills of the trainable mentally retarded, it can be stated that the posttest average of each visual perception sub-scale average except the shape-ground connection has increased. When movement skills were reviewed, it is considered that Montessori education should be used more widely. The significant results in the control group reveal that education depending on the repetition of the actions provides success as in Montessori education. Therefore, it is considered that practices for Montessori education can be performed along with the traditional education programs in disabled centers.

The importance of Montessori education in mentally disabled individuals emerges. It can be recommended that in other studies mentally retarded individuals given classical and Montessori education should be compared with the ones who have not had any education, and the importance of both classical and Montessori education for mentally retarded individuals should be emphasized. It is recommended Montessori education should be used widely for mentally retarded since Montessori education for mentally retarded, unlike classical education, includes family members in the center of the education and affect the students positively in many ways. 


\section{References}

Açak, M., \& Kaya, O. (2015). İşitme engelli ve işitme engelli olmayan futbolcuların benlik saygıları ve saldırganlık düzeylerinin incelenmesi. Inonu University, Journal of Physical Education and Sport Sciences, 2(2), 1-11.

Açıkada, C. (Ed.) (2008). Atletizm Yetenek Modeli Raporu. Ankara: Atletizm Federasyonu Eğitim Kurulu Yayınları. [.

Akçin, N. (1993). Okuma becerisinin kazandırllmasında görsel algl gelişiminin rolü. Master Thesis, Hacettepe University, Graduate School of Health Sciences, Ankara.

Akdemir, B. (2006). Visual apprehension ability evaluating gauger, mentally defective students in between 6-12 years. Master Thesis, Selçuk University, Graduate School of Social Sciences, Child Development and House Management, Konya.

Aksay, E., Arslan, C., Botter, V., \& Güllü, M. (2011). The Effect of athletics on movement skill levels caused by peripheral and central nervous system with disabled. Selçuk University Journal of Physical Education and Sport Science, 13(Suplement), 95- 98.

Akyol, B., \& Güllü, M. (2014). Identifying the affect of hand abilities on the level of motor and disabilities in cerebral palsy children. Inönü Journal of Vocational School of Health Service, 2(1), 1-9.

Ansari, A., \& Winsler, A. (2014). Montessori public school pre-K program sand the school readiness of low-income black and latino children. Journal of Educational Psychology, 106(4), 1066-1079. https://doi.org/10.1037/a0036799

Asliyüksek, M. (2015). Investigation of Montessori education method on the development of motor skills, visual perception \& memory, hand - eye coordination and motor skills of 4 - 5 years old children. Master Thesis, Fatih University, Graduate School of Social Sciences, İstanbul.

Atan, T., Eliöz, M., Çebi, M., Ünver, Ş., \& Atan, A. (2016). Investigation of the effect of basketball training on motoric skills of the educable mentally retarded children. Journal of Sports and Performance Researches, 7(1), 29-35. https://doi.org/10.17155/spd.78754

Barbarin, O. A., Early, D. Clifford, R., Bryant, D., Frome, P., Burchinal, M. Howes, C., \& Pianta, R. (2008). Parental conceptions of school readiness: Relation to ethnicity, socio-economic status, and children's skills. Early Education \& Development, 19(5), 671-701. https://doi.org/10.1080/10409280802375257

Bhatia, P., Davis, A., \& Shamas-Brandt, E. (2015). Educational gymnastics: The Effectiveness of montessori practical life activities in developing fine motor skills in kindergartners. Early Education and Development, $26(4), 594-607$. https://doi.org/10.1080/10409289.2015.995454

Boehnlein, M. M. (1990). Research and evaluation summary of Montessori programs. (D. Khan Ed.). Implementing Montessori Education in the Public Sector. Cleveland Heights: North American Montessori Teachers Association, pp: 476-483.

Epstein, J. (1986). Parents' reactions to teacher practice of parent involvement. The Elementary School Journal, 86(3), 277-294. https://doi.org/10.1086/461449

Ervin, B., Wash, P. D., \& Mecca, M. E. (2010). A 3-year study of self-regulation in Montessori and non-montessori classrooms. Montessori Life, 22(2), 22-31.

Hetzler, R. K., Stickley, C. D., Lundquist, K. M., \& Kimura, I. F. (2008). Reliability and accuracy of handheld stopwatches compared with electronic timing in measuring sprint performance. J Strength Cond Res, 22(6), 19691976. https://doi.org/10.1519/JSC.0b013e318185f36c

Kagitcibasi, C., Sunar, D., \& Bekman, S. (2001). Long-term effects of early intervention: Turkish low-income mothers and children. Journal of Applied Developmental Psychology, 22(4), 333-361. https://doi.org/10.1016/S0193-3973(01)00071-5

Kahn, D. (1990). Implementation. (Ed., D. Kahn). Implementing montessori education in the public sector. Cleveland Heights: North American Montessori Teachers Association. pp:474.

Karahan, M., Demir, R., Şahin, İ., \& Süel, E. (2007). The Effect of training on educable mental retarded children's some motor ability. Niğde University, Journal of Physical Education and Sports Science, 1(2), 71-75.

Kayıl1, G. (2016). The effect of Montessori method on cognitive tempo of kindergarten children. Early Child Development and Care, 188(3), 327-335. https://doi.org/10.1080/03004430.2016.1217849

Lillard, A. S. (2008). Montessori: The science behind the genius. New York: Oxford University Press. 
Mackenzie, B. (2005). 101 Performance Evaluation Tests. London: Electric World plc. pp: 92-93.

Merriman, W. J., Barnett, B. E., \& Jarry, E. S. (1996). Improving fitness of dually diagnosed adults. Perceptual and motor skills, 83(3), 999-1004. https://doi.org/10.2466/pms.1996.83.3.999

Montessori, M. (2014). Spontaneous activity in education. New York: Fredrick A. Stokes Company.

Montessori, M. (2015). Emici Zihin. (Translate: Okhan Gündüz). İstanbul: Kaknüs Yayınları.

Oğuz, V., \& Köksal Akyol, A. (2006). Çocuk eğitiminde Montessori yaklaşımı. Journal of Çukurova University Institute of Social Sciences, 15(1), 243-256.

Ryan, J., Ashwood, E., \& Puckeridge, S. (2010). The Development of anger management skills in adults with moderate intellectual disability. Department of Communities, Disability and Community Care Services. 45th Annual Board Conference Brisbane.

Sağol, U. (1998). The Effects of frostig visual perception training programe to visual perception development of the children with down syndrome. Master Thesis. Marmara University, Institute of Social Sciences, pp: 51-73.

Savucu, Y., Sirmen, B., İnal, S., Karahan, M., \& Erdemir, İ. (2006). Determination the Effects of Basketball Training to the Physical Fitness of People with Mental Disabilities. Firat University Medical Journal of Health Sciences, 20(2), 105-113.

Tamer, K. (2000). Sporda fiziksel-fizyolojik performansın ölçülmesi ve Değerlendirilmesi. Ankara: Bağırgan Yayımevi.

Tınazcı, C., Emiroğlu, O., \& Burgul, N. (2004). KKTC 7-11 yaş klz ve erkek ilkokul ögrencilerinin eurofit test bataryası değerlendirilmesi. The 10th ICHPER SdEuropa Congress and The TSSA 8th International sports Science Congress, November, Antalya, Turkey.

Vossen, J. F., Kramer, J. E., Burke, D. G., \& Vossen, D. P. (2000). Comparison of dynamic push-up training and plyometric push-up training on upper-body power and strength. J Strength Cond Res, 14(3), 248-53.

Yıldız, F. Ü. (2018). Mother support of montessori education program; Montessori education area children ages 4-5, investigation of effect of mathematics and daily life skills. Doctorate Thesis. Selçuk University, Graduate School of Social Sciences, Konya.

Zorba, E. (2000). Physical Fitness. Ankara: Neyir.

\section{Copyrights}

Copyright for this article is retained by the author(s), with first publication rights granted to the journal.

This is an open-access article distributed under the terms and conditions of the Creative Commons Attribution license which permits unrestricted use, distribution, and reproduction in any medium, provided the original work is properly cited. 